\title{
Evaluation of the Demand for Patent Services Making Outsourcing Contracts
}

The research includes comparative analysis of the statistical data considering distribution of national patent applications and PCT national phase entries. The results reveal, whether companies are inclined to engage outsourcing services of patent attorneys or hire a lawyer inside.

Keywords: transaction costs, patents, patent rights, efficiency, patent attorney.

Straipsnyje atliekama lyginamoji statistinių duomenų apie nacionalinių patentų prašymų bei tarptautinių paraiškų, perèjusių į nacionalinị lygị, pasiskirstymo analizė. Tyrimo rezultatai atskleidžia, ar ịmonès yra linkusios pasitelkti išorines patentų teisininkų paslaugas, ar samdyti teisininką darbui įmonés viduje.

Raktiniai žodžiai: sandorio kaštai, patentai, efektyvumas, patentinis patiketinis.

\section{Introduction}

Despite general recognition of the importance of intellectual property as a collective function, the peculiarities of arranging the services related to intellectual property inside companies are hardly considered. Among all publications, which present short descriptions of intellectual property studies, the articles written by Y. Chen, I. J. Horstmann, J. R. Markusen (2012), E. S. Langer (2012), K. L. Mayer, D. Somaya and I. O. Williamson (2012) should be noted. In these studies, the authors systematise the functions of intellectual property departments and describe the particularities of integration of these functions into general environment. During recent years, companies and institutions face the necessity to unify investment decisions which are related to physical and financial assets as well as intellectual resources. This often generates additional transaction costs hiring high-skilled employees, implanting new organisational processes, procedures, improving organisational structure and so forth.

On December 12, 2012, The European Parliament confirmed The EU Unitary Patent Package for the unitary patent, its linguistic mode and the General Patent Court. When the new system comes into force,

Vytautas SNIEŠKA - PhD, prof., Kaunas University of Technology. Address: Laisvès al. 55, LT-44309 Kaunas. E-mail: vytautas.snieska@ktu.kt.

Ligita GASPARĖNIENĖ - PhD, doc., Kaunas University of Technology. Address: Laisvès al. 55, LT-44309 Kaunas. E-mail: ligita.vasiliauskiene@ktu.lt. 
it will make Europe-wide patenting much easier and cheaper. However, for the same reason, a bigger number of patents will become valid not only in the country of their origin but also in all EU zone, so the companies will have to analyse the juridical environment more attentively before implementing new technological decisions. The International Agreement will enter into force on January 01, 2014, or after it has been ratified by at least 13 participating countries, including the United Kingdom, France and Germany. The ratified package will ensure cheaper and more efficient patent protection for small and medium companies. It is expected that the new system will promote innovations and make favourable conditions for small and medium enterprises to protect their inventions under the general European patent. With reference to the data of the European Commission, the new patent will be cheaper and more efficient in comparison to the current system. The new regime will provide protection for the unitary patent in all 25 member-countries, with the exception of Spain and Italy which have not joined the system proposed. It is considered that European unitary patent could cost seven times cheaper than currently (4.725 EUR instead of its current average price 36.000 EUR).

During 2011, 32 applications for the European unitary patent were received from Lithuania. It is projected that lower price of the patent will cause the number of patent applications from Lithuania to grow. At present, the biggest number of applications for the European unitary patent comes from such countries as the USA (60.000), China (17.000) and Korea (13.000). The dynamics of the application number from these countries still remains unclear. Henceforth, any inventor can apply to the European Patent Office in English, German or French. Applying in other language, translation to one of the main languages of European Patent Office will be required.

In order to make patent information available to all people concerned, the system of unitary patent ensures that the descriptions of patent applications and patents themselves will automatically be translated to all official EU languages. Nevertheless, such translations will be used only for informative aims and will have no juridical power. Once the company has any doubts that the technical decisions applied or intended to be applied can violate competitors' patent rights, it is recommendable to consult a professional for proper evaluation of particular patent's protection range (Serenko, Bontis, Booker, 2010).

The regulations define that during the transition period of the system, the quality of automatic evaluation should be regularly and objectively performed by the committee of independent experts established in the European patent organisation by the member-countries. The members of the committee would be the representatives of the European Patent Office and the users of the European patent system. The proposed regulations define that assessing the responsibility for the violation of patent rights, suspected violator's size and the nature of activities will be considered. It means that in case of litigation, the court will have to decide whether the suspected violator, especially if it is a small or medium enterprise, an individual, a nonprofit organisation or a public research institution, acted without knowing about the violation of the patent rights until receiving the patent translation. 
The costs of such translation will have to be covered by the patent owner.

It is important to note that translations make the biggest part of patenting costs. Henceforth, these costs will be fully covered for small and medium enterprises, non-profit organisations, universities and public research institutions.

Companies (patent attorneys) provide the assistance for applicants to prepare the applications for compensation and represent patenting companies in their relations with the Agency for Science, Innovation and Technology.

The target of the article is to evaluate the demand for patent services making outsourcing contracts.

The object of the research is the demand for patent services making outsoursing contracts.

The methodology of the research includes systematic and comparative analysis of the scientific literature and the analysis of the statistical data.

The results of the empirical research enabled to establish the demand for patent services in companies making outsourcing contracts each year of the research, evaluate demand volatility and compare the demand for patent services making outsourcing contracts in different industries.

\section{Transaction costs of intellectual capital formation}

According to D. A. A. Klein (2012), intellectual capital is a combination of human and structural resources (especially the relative ones) in an organisation.

Human capital, according to M. Moeen, D. Somaya and J. T. Mahoney (2013), is the integration of non-material assets implanted in the staff of the company. Four types of these resources are distinguished:

- competences (including skills and abilities);

- outlooks (motivation and managers' leadership abilities);

- intellectual flexibility (abilities of organisation members to think fast and intellectually);

- innovations and entrepreneurship (abilities to adapt, intercross ideas and so forth).

Structural capital is everything "that remains in the company after 5 o'clock p.m." (Serenko et al., 2010; Chen et al., 2012). It is information and knowledge that remain in the company after the end of the work day. These are also organisational processes, procedures, systems, culture, databases and so forth. Structural capital can be divided into relative capital (related with external subjects such as suppliers, customers, allies, local communities, authorities, shareholders and others), organisational capital (for instance, structures, culture, routines, processes) and renewal and development (all future projects including new equipment, products and so forth).

The costs of intellectual capital are difficult to measure since it is hard to estimate both the value of human capital and the value of structural capital (the value of human capital includes not only wages, and the value of organisational culture or databases is difficult to measure quantitatively). That is why it is purposeful to estimate the efficiency of human and structural capital, and total efficiency of the both elements would reflect the overall efficiency of intellectual capital (Gigante, Previati, 2010). Theoretical literature of transaction costs offers to calculate the coefficient of Value Added Intellectual Coefficient. 
Value Added Intellectual Coefficient is an analytical measure designed to evaluate the efficiency of the activities in an organization (Langer, 2012). It shows the efficiency of total value creation in an organization. Intellectual Capital Efficiency (ICE) describes the efficient use of intellectual capital in an organization. This model is based on the presumption that value creation has originated from two main kinds of resources: the resources of physical capital and the resources of intellectual capital. In fact, Value Added Intellectual Coefficient shows total efficiency of the value, created from all resources available in the organisation, and ICE reflects total efficiency of the value created using intellectual capital. The better the organisation uses its resources, the higher is the efficiency of value creation.

The research of the recent time reveals that management of non-material assets which is the essential factor influencing companies' long-term business success, requires special management methods and skills (Soby, Kandasamy, Saberwal, 2012; Standfield, 2002; Sharabati, Jawad, Bontis, 2010). It is also proposed that active management of intellectual capital in companies is a necessary condition of future profits (Lev, 2004; Reitzig, 2004) because although physical capital is important for the activities of organisations, intellectual capital helps to ensure the quality of the services for customers.

The management of intellectual property a lot depends on the nature of the assets and the opportunities to protect them: management of the assets that cannot be protected using formal legal instruments, is usually performed by the internal units of the organisation and has a direct link with knowledge management and human resources management (Soby et al., 2012; Sharabati et al., 2010; Mayer et al., 2012). Due to the different nature of intellectual assets and wide variety of legal instruments, the management of property rights (for example, patent rights) is usually performed by separate departments of companies or organisations (Zedtwitz, Gassmann, Boutellier, 2004; Pitkethly, 2001; Chen et al., 2012).

The companies that do not patent inventions themselves, but work in the industries with many new patented technologies, often face the risk of the violation of patent rights and litigation. Since acquiring, maintenance and use of legally based, systematised patent rights is a significant part of intellectual property management in companies, patent costs are one of the main aspects of the analysis of intellectual capital transaction costs.

According to R. H. Pitkethly (2001), the functions of patent departments in companies can be easily classified by two criterions. First, patent-related services can be different by their strategic importance for the company. Second, patent departments have to perform the tasks related with competitors and competition, i.e. not internal but external tasks. For instance, creation and filling of patent application form in the patent office or administration of current patent portfolio are little related to competitors' activities, so have low strategic importance for the company. The functions related to competitors are more operative than strategic. They include the functions of litigation (both defence and prosecution), preparation, submission of claims and attendance of court hearings.

Alongside with these repeated and well-structured operative tasks, the departments of intellectual property perform the functions that are of big strategic 
importance for the company. These are activities linked with competitors - prospecting for new technologies and future trends or long-term patent portfolio planning. The last function is considered to be essential, particularly for the companies operating in the industries with many patents, where patents are the subject of negotiation or they are exchanged applying licensing agreements (Hall, Ziedonis, 2001; Ham-Ziedonis, 2004). What is more, there are types of activities that are not directly related to competitors, but also have long-term importance. These activities usually include employment and maintenance of the staff to work in the department of intellectual property as well as research and development activities projected to ensure unlimited communication channels among the inventors, researchers and patent professionals.

With reference to J. H. Knight (2001) and R. H. Pitkethly (2001), if the company decides to perform patent-related activities inside, patent departments are usually headed by patent attorneys with proper education. Nevertheless, patent department in the company is always of limited size with limited number of employees, although the variety of the tasks performed is very wide: from organisation of short-term patent-related activities (analysis of the patentable inventions, preparation of applications considering formal requirements and so forth) to long-term plans and coordination of research and development projects (product improvement, development of patent portfolio, analysis of competitors and so forth). In fact, many companies actively acquire intellectual property rights, but they do not have any appropriate departments for the administration of intellectual property to be able to handle the increased load of administrative work. Due to this reason, the companies that steadily seek for intellectual property protection for their technical inventions are inclined to use the services of outside suppliers, if their patent department cannot handle increased work load or if they do not form any patent department inside the company and trust only the services of outside suppliers, for example, patent attorneys.

Next part of the article presents the statistical analysis of the data on patent applications and patent attorneys. With reference to the transaction costs economics and the theories of resource management, it can be presumed that the use of outside patent services is rather homogenous considering the features of human capital. It means that every time filling a patent application one can need specific technical knowledge and that it is practically impossible to indicate the applications that require more technical preparation than the others.

\section{Statistical analysis}

It is obvious that the demand of different companies for patent services is also different considering not only absolute frequency of applications but also demand fluctuations (uncertainty). Scientific research includes quite extensive empirical analyses of the demand for patent services, usually leaning on the features of the demand for services and propositions of the transaction costs economics, i.e. it has been analysed what factors motivate companies to use external patent services or perform the activities of this kind inside the company. The scientific research has established that the decision often 
depends on the frequency of patent applications (Houseman, 2001; Business and Patent Information Services, 2013). The decision to maintain patent department inside the company is not cost-effective for small companies. Even if a small company is capable of retaining full-time patent experts, and fully exploits the capabilities of patent department, the biggest part of the work performed by the employees in this department consists of daily routine works (for example, execution of procedures, paying taxes for patent renewal and so forth) while solution of the complex problems remains unmanaged and uncontrolled. In this case, the company would benefit from using the services of the experts from outside. Due to this reason, small companies can decide to operate without any patent department.

Table 1 shows the distribution of the number of patent applications presented by individuals and juridical entities during the period of 2008-2011.

The data presented in Table 1, reveals that the number of patent applications submitted by juridical entities in 2008, 2009 and 2010 was lower than the number of individual applicants. However, in 2011, the number almost levels off. It shows that juridical entities in Lithuania have become more active protecting their intellectual property. The results of the analysis of the links between the demand for patent services and the decision of the company to use outsourcing proposes that higher demand for patent services determines lower level of outsourcing (Cohen, Nelson, Walsh, 2000).

Table 2 shows the distribution of national patent applications and PCT national phase entries by the country of origin in 2008-2012.

According to the data of The State Patent Bureau of the Republic of Lithuania (2013), in 2008, 99 national patent applications as well as 6 PCT national phase entries were received, including 87 filled by Lithuanian applicants and 20 filled by foreign applicants. In 2009, 107 patent applications were received, 98 of which were national applications and 9 were PCT national phase entries, including 91 filled by Lithuanian applicants and 16 filled by foreign applicants. 114 patent applications: 112 national applications as well as 2 PCT national phase entries, including 108 by Lithuanian applicants, 6 by foreign applicants, were filed in 2010. 108 patent applications: 103 national applications as well as 5 PCT national phase entries, including 93 by Lithuanian applicants, 15 by foreign applicants, were filed in 2011. Finally, 124 patent applications: 118 national applications as well as 6 PCT national phase entries, including 109 by Lithuanian applicants, 15 by foreign applicants, were filed in 2012 .

Distribution of the number of patent applications by the applicant during the period of 2008-2011

Table 1

\begin{tabular}{|l|c|c|c|c|}
\hline \multirow{2}{*}{\multicolumn{1}{c|}{ Applicant }} & \multicolumn{4}{c|}{ Year } \\
\cline { 2 - 5 } & $\mathbf{2 0 0 8}$ & $\mathbf{2 0 0 9}$ & $\mathbf{2 0 1 0}$ & $\mathbf{2 0 1 1}$ \\
\hline Juridical entities & 38 & 39 & 44 & 46 \\
\hline Individuals & 51 & 52 & 64 & 47 \\
\hline Total & 89 & 91 & 108 & 93 \\
\hline
\end{tabular}

Source: The State Patent Bureau of the Republic of Lithuania (2012). 
Distribution of national patent applications and PCT national phase entries

by the country of origin in 2008-2012

\begin{tabular}{|c|c|c|c|c|c|}
\hline \multirow{2}{*}{ State } & \multicolumn{5}{|c|}{ Year } \\
\hline & 2008 & 2009 & 2010 & 2011 & 2012 \\
\hline AT & & 1 & & & \\
\hline $\mathrm{DE}$ & 3 & 3 & & & \\
\hline DK & 3 & & & 1 & \\
\hline $\mathrm{EE}$ & 1 & 3 & & 1 & 1 \\
\hline ES & 1 & & & 1 & \\
\hline GB & 1 & & & & \\
\hline LT & 87 & 91 & 108 & 93 & 109 \\
\hline LV & 3 & 2 & 1 & & 1 \\
\hline RU & 6 & 3 & 1 & & \\
\hline FR & & 1 & & & \\
\hline IN & & 1 & & & \\
\hline TW & & 2 & 1 & & \\
\hline CZ & & & 2 & 6 & 2 \\
\hline US & & & 1 & 1 & 2 \\
\hline FI & & & & 1 & \\
\hline $\mathrm{HU}$ & & & & 1 & \\
\hline IT & & & & 1 & \\
\hline MX & & & & 1 & \\
\hline TD & & & & 1 & \\
\hline IL & & & & & 1 \\
\hline $\mathrm{JP}$ & & & & & 3 \\
\hline NZ & & & & & 2 \\
\hline $\mathrm{PL}$ & & & & & 2 \\
\hline SE & & & & & 1 \\
\hline Total: & 105 & 107 & 114 & 108 & 124 \\
\hline
\end{tabular}

Source: The State Patent Bureau of the Republic of Lithuania (2013).

The results of the analysis have revealed that vast majority of individuals and legal entities who have submitted applications for patents, use the services of patent attorneys. However, it should be noted that Lithuanian Patent Office does not keep any statistics on whether patent documentation is prepared inside the companies or trusting patent attorneys. Even if the company has formed a patent department, its employees are responsible only for strategic planning and coordination of the contracts with outside service suppliers.

\section{Analysis of patent applications in different industries}

Considering the fact that the necessity to acquire a patent as a measure of intellectual property protection can differ depending on the industry where the company operates, from scientific point of view, it is purposeful to analyse the links between the 
decision of the company to make a transaction for patent service provision and the necessity to use the resources of this kind.

Due to the fact that making an outsourcing contract, a part of company's resources is transferred to a service provider from outside, companies should seek to retain the resources of great strategic value. That is why outsourcing transactions should be made only for the resources that have low strategic value for the company (Moeen et al., 2013; Gilley, Rasheed, 2000). So, the number of outsourcing transactions for patent service provision is smaller in industries where patents are considered to have big strategic value for companies.

With reference to the data presented by European Patent Office, provided by Online European Patent Register, and the information obtained from 107 European companies about the number of employees and the expenses for the activities of research and development, S. Wagner (2006) established that more than 60 per cent of the companies included in the research during the period of 1980-2010, used external services provided by patent attorneys for filling patent applications. So, it can be stated that most companies in
Europe are inclined to make outsourcing contracts for patent service provision but not to keep a patent department inside the company. This tendency can be observed during all the period of the research.

Analysing the distribution of patent applications in different industries, it has been established that in Lithuania, the rights of intellectual property are usually formalised in the spheres of human needs (21 application), mechanics, lightning, heating, guns, blasting (19 applications) and physics (15 applications) (the detailed data has been presented in Table 3 ).

The smallest number of patent applications was filled in the spheres of textile ( 1 application) and electricity ( 3 applications). So, with reference to the analysis of the scientific literature, patent services have relatively high strategic value for the industries of human needs, mechanics, lightning, heating, guns, blasting and physics, and have relatively low strategic value for the industries of textile and electricity.

Summarizing, demand for patent services and fluctuations of this demand are the main factors, determining the number of outsourcing transactions for patent

Distribution of patent applications in different industries in Lithuania in 2011

Table 3

\begin{tabular}{|l|c|c|}
\hline \multicolumn{1}{|c|}{ Industries } & $\begin{array}{c}\text { Industry code } \\
\text { by the classifier }\end{array}$ & $\begin{array}{c}\text { Number of patent } \\
\text { applications }\end{array}$ \\
\hline Human needs & $\mathrm{A}$ & 21 \\
\hline Different technological processes, transport & $\mathrm{B}$ & 8 \\
\hline Chemistry, metallurgy & $\mathrm{C}$ & 13 \\
\hline Textile, paper & $\mathrm{D}$ & 1 \\
\hline Construction, mining & $\mathrm{E}$ & 5 \\
\hline Mechanics, lightning, heating, guns, blasting & $\mathrm{F}$ & 19 \\
\hline Physics & $\mathrm{G}$ & 15 \\
\hline Electricity & $\mathrm{H}$ & 3 \\
\hline Total & - & 85 \\
\hline
\end{tabular}

Source: The State Patent Bureau of the Republic of Lithuania (2012). 
services. At the same time, the decision of the company to make outsourcing contracts is influenced, at least indirectly, by the importance of patents to the particular company. The results of the analysis of the scientific literature confirm the presumptions of the transaction costs economics and theory of the resources that companies use outsourcing services in order to balance work load for their staff. Performing the research of this kind in the future, it is purposeful to analyse the links between companies' organizational structures and transactions for patent services because from a broader prospective, these links can provide a more complete picture of outsourcing transactions for knowledge-intensive business services.

\section{Conclusions}

1. The results of the analysis of the scientific literature confirm the presumptions of the transaction costs economics and theory of the resources that companies use outsourcing services in order to balance work load for their staff.

2. The demand for patent services and fluctuations of this demand are the main factors, determining the number of outsourcing transactions for patent services. At the same time, the decision of the company to make outsourcing contracts is influenced, at least indirectly, by the importance of patents to the particular company.

3. The results of the analysis have revealed that vast majority of individuals and legal entities who have submitted applications for patents, use the services of patent attorneys. However, it should be noted that Lithuanian Patent Office does not keep any statistics on whether patent documentation is prepared inside the companies or trusting patent attorneys.

4. Patent services have relatively high strategic value for the industries of human needs, mechanics, lightning, heating, guns, blasting and physics, and have relatively low strategic value for the industries of textile and electricity.

\section{References}

1. Business and Patent Information Services. (2013). Patent Searches. Internet access: <http:// www.businessandpatents.org/content/index. php? option $=$ com_content $\&$ view $=$ article $\&$ id $=38$ \&Itemid=29>, [accessed May 10, 2013].

2. Chen, Y., Horstmann, I. J., Markusen, J. R. (2012). Physical Capital, Knowledge Capital, and the Choice between FDI and Outsourcing // Canadian Journal of Economics. Vol. 45 (1), p. 1-15. doi: 10.1111/j.1540-5982.2011.01684.x.

3. Cohen, W. M., Nelson, Walsh, J. P. (2000). Protecting Their Intellectual Assets: Appropriability Conditions and Why U.S. Manufacturing Firms Patent (or not) // NBER Working Paper. February, No. 7552.

4. Gigante, G., Previati, D. (2010). The Performance of Intellectual Capital and Banking: Some
Empirical Evidence from the European Banking System / New Issues of Financial Institutions Management - Palgrave Macmillan Studies.

5. Gilley, M. K., Rasheed, A. (2000). Making More by Doing Less: An Analysis of Outsourcing and its Effects on Firm Performance. // Journal of Management. Vol. 26, No.4, p. 763-790.

6. Hall, B., Ziedonis, R. (2001). The Determinants of Patenting in the U.S. Semiconductor Industry // RAND Journal of Economics, Vol. 32 (1), p. 101-128.

7. Ham-Ziedonis, R. (2004). Don't Fence Me In: Fragmented Markets for Technology and the Patent Acquisition Strategies of Firms // Management Science. Vol. 50, No. 6, p. 804-820.

8. Houseman, S. N. (2001). Why employers use flexible staffing arrangements: Evidence from an 
establishment Survey //Industrial and Labor Relations Review. Vol. 55, No. 1, p. 149-170.

9. Klein, D. A. A. (2012). The Strategic Management of Intellectual Capital - Woburn: Butterworth-Heinemann.

10. Knight, J. H. (2001). Patent Strategy for Researchers and Research Managers. 2nd ed. - John Wiley \& Sons, Ltd.

11. Langer, E. S. (2012). Biomanufacturing Outsourcing Outlook. Internet access: <http:// www.biopharminternational.com/biopharm/ article/articleDetail.jsp? $\mathrm{id}=757935 \& \mathrm{sk}=$ \&date $=$ \&pageID=3>, [accessed May 10, 2013].

12. Lev, B. (2004). Sharpening the Intangibles Edge // Harvard Business Review. Vol. 86 (6), p. 109-116.

13. Mayer, K. L., Somaya, D., Williamson, I. O. (2012). Firm-Specific, Industry-Specific, and Occupationa Human Capital and the Sourcing of Knowledge Work // Organization Science. Vol. 23, p. 1213-1226. doi: 10.1287/orsc.1110.0722.

14. Moeen, M., Somaya, D., Mahoney, J. T. (2013). Supply Portfolio Concentration in Outsourced Knowledge-Based Services // Organization Science. Vol. 24, p. 262-279. doi: 10.1287/ orsc. 1110.0725 .

15. Pitkethly, R. H. (2001). Intellectual Property Strategy in Japanese and UK Companies: Patent Licensing Decisions and Learning Opportunities // Research Policy. Vol. 30(3), p. 425-442.

16. Reitzig, M. (2004). Strategic Management of Intellectual Property // Sloan Management Review. Vol. 45(3), p. 35-40.

17. Serenko, A, Bontis, N., Booker, L. et al. (2010). A sientometric analysis of knowledge manage- ment and intellectual capital academic literature // Journal of Knowledge Management. Vol. 14 (1), p. 3-23. doi: 10.1108/13673271011015534.

18. Sharabati, A. A., Jawad, S. N., Bontis, N. (2010). Intellectual capital and business performancein the pharmaceutical sector in Japan // Management Decision. Vol. 48(1), p. 105-131. doi: 10.1108/00251741011014481.

19. Soby, S., Kandasamy, M., Saberwal, G. (2012). Work outsourced to Indian biotech and pharma companies is not yet significantly innovative / Current Science. Vol. 102 (3), p. 401 - 404.

20. Standfield, K. (2002). Intangible Management Amsterdam: Academic Press.

21. The State Patent Bureau of the Republic of Lithuania. (2012). Annual Report for the year 2011 of the State Patent Bureau of the Republic of Lithuania. Internet access: <http://www.vpb. lt/metines_at/VPB_2011.pdf $>$, [accessed May 10, 2013].

22. The State Patent Bureau of The Republic of Lithuania. (2013). Statistics on the legal protection of industrial property in the Republic of Lithuania. Internet access: <http://www.vpb.gov.lt/index.php? $\mathrm{p}=0 \& \mathrm{l}=\mathrm{lt} \& \mathrm{n}=308>$, [accessed May 10, 2013].

23. Wagner, S. (2006). Make-or-Buy decisons in Patent Related Services. University of Munich. Working paper. Internet access: <http://ssrn. com/abstract $=1099384>$, [accessed April 24, 2013].

24. Zedtwitz, M., Gassmann, O., Boutellier, R. (2004). Organizing global R\&D: Challenges and dilemmas // Journal of International Management. Vol. 10, p. 21-49.

The paper submitted: May 15, 2013

Prepared for publication: September 16, 2013

Vytautas SNIEŠKA, Ligita GASPARÉNIENĖ

\section{PAKLAUSOS PATENTŲ PASLAUGOMS SUDARANT IŠORNAUDOS KONTRAKTUS IVERTINIMAS}

\section{S a n t r a u k a}

Kaip nurodoma mokslineje literatūroje, intelektinio kapitalo valdymas yra būtina sąlyga kompanijoms užsitikrinti pelningumą ateityje (Lev, 2004; Reitzig, 2004). Nors fizinis kapitalas yra gyvybiškai būtinas gamybai, logistikai ir sklandžiam darbo organizavi- mui, intelektinis kapitalas padeda užtikrinti kokybę vartotojams ir diegti inovacijas. Nepaisant bendrosios intelektinio kapitalo funkcijos, paslaugų, susijusių su intelektine nuosavybe, organizavimo ypatybès yra vis dar menkai ištirta sritis. 
Intelektinio kapitalo kūrimas paprastai sukuria papildomus aukštos kvalifikacijos darbo jègos samdymo, naujų organizacinių procesų ir procedūrų diegimo, organizacinès struktūros tobulinimo ir pan. kaštus. Intelektinio kapitalo sandorių kaštai yra sunkiai išmatuojami, kadangi yra sudėtinga apskaičiuoti tiek žmogiškojo kapitalo, tiek struktūrinio kapitalo vertę (žmogiškojo kapitalo vertè apima ne tik darbo užmokestị, o organizacinès kultūros ar duomenų bazių vertę yra sunku išmatuoti kiekybiškai). Kadangi teisiškai pagrịstų, susistemintų patentų teisių igijimas ir išlaikymas yra viena pagrindinių intelektinio kapitalo valdymo įmonèse užduočių, paklausos patentų paslaugoms sudarant išornaudos kontraktus ịvertinimas yra reikšminga tyrimų sritis.

Tyrimas, pristatomas šiame straipsnyje, apima lyginamąją statistinių duomenų apie nacionalinių patentų prašymų bei tarptautinių paraiškų, perejjusių ì nacionalinị lygi, pasiskirstymo analizę pagal kilmès (pareiškejjo) šali arba pramoninès nuosavybės teisių igijeją. Tyrimo rezultatai parodo, ar i̇monès yra linkusios pasitelkti išorines patentų teisininkų paslaugas dirbti su patentų registracijos dokumentais, ar samdo teisininką pastoviam darbui ¡̇monès viduje.

Straipsnio tikslas - įvertinti paklausą patentų paslaugoms sudarant išornaudos kontraktus.
Tyrimo objektas yra paklausa patentų paslaugoms sudarant išornaudos kontraktus.

Tyrimo metodika apima sisteminę ir lyginamąją mokslinès literatūros ir statistinių duomenų analizę.

Mokslinès literatūros analizès rezultatai patvirtina sandorio kaštų ekonomikos ir išteklių teorijos prielaidas, kad įmonès naudojasi išorinèmis paslaugomis tam, kad subalansuotų savo personalo darbo krūvị. Paklausa patentų paslaugoms bei jos svyravimai yra pagrindiniai veiksniai, lemiantys išornaudos sandorių patentų paslaugoms skaičių. Tuo pat metu, i̇monès sprendimas sudaryti išornaudos kontraktą yra ịtakojamas, bent jau netiesiogiai, patentų svarbos tam tikrai įmonei. Tyrimo rezultatai atskleide, kad didžioji dauguma privačių ir juridinių asmenų, kurie yra pateikę patentų prašymus, naudojasi patentų teisininkų paslaugomis. Tačiau reikia pažymèti, kad Lietuvos Valstybinis Patentų Biuras neturi statistikos apie tai, ar patentų dokumentacija yra ruošiama įmonių viduje, ar pasikliaujant patentų teisininkais. Patentų paslaugos turi sąlyginai didelę strateginę vertę tokioms ūkio šakoms, kaip žmogiškieji poreikiai, mechanika, apšvietimas, šildymas, ginklai, sprogdinimai ir fizika, ir sąlyginai žemą strateginę vertę tokioms ūkio šakoms, kaip tekstilè ir elektros tiekimas. 